\title{
PENGARUH PENDAPATAN DAN SUKU BUNGA TERHADAP KEPUTUSAN PENGAMBILAN KPR PADA PT BANK TABUNGAN NEGARA (PERSERO) TBK CABANG PRABUMULIH
}

\author{
Emi Sukmawati \\ Program Studi Akuntansi Sekolah Tinggi Ilmu Ekonomi \\ Yayasan Pendidikan Prabumulih (STIE YPP) \\ Email: emisukmawati579@gmail.com
}

\begin{abstract}
This study is entitled "The Effect of Income and Interest Rates on the Decision of Taking Mortgages at PT Bank Tabungan Negara (Persero) Tbk Prabumulih Branch". The main problem in this research is how much income and interest rates influence the decision to take KPR at PT Bank Tabungan Negara (Persero) Tbk Prabumulih Branch. Determination of the sample in this study is to use the accidental sampling method, namely random sampling. The number of samples studied were 100 respondents who worked, both as private employees, BUMN employees, and Civil Servants (PNS) who were classified based on the income they received per month. The analytical method used is multiple linear regression with hypothesis testing using the F test, $t$ test, and the coefficient of determination ( $R 2)$. The results of this study concluded that income and interest rates influence the decision to take a mortgage at PT. Bank Tabungan Negara (Persero) Tbk Branch Prabumulih of 46.8\%. Researchers give advice, companies engaged in housing should really pay attention to what factors are very influential in determining the buyer's decision to take a mortgage so that companies avoid unwanted problems, such as bad loans
\end{abstract}

Keywords: Income, Interest Rates and Decision Making

\section{Dasar Pemikiran}

Kebutuhan primer akan perumahan merupakan kebutuhan yang sangat penting dan bersifat mendesak untuk segera dipenuhi. Selain sebagai tempat tinggal kepemilikan rumah dapat juga dijadikan sebagai sarana investasi untuk jangka panjang bagi masyarakat yang mampu. Seiring perkembangan penduduk maka kebutuhan rumah terus bertambah, melihat hal tersebut pemerintah selalu berusaha membantu masyarakat 


\section{4}

Emi Sukmawati, PENGARUH PENDAPATAN DAN SUKU BUNGA TERHADAP KEPUTUSAN...........

terutama masyarakat menengah ke bawah untuk memenuhi kebutuhan tempat tinggal mereka diantaranya dengan menyalurkan kredit murah untuk pembelian perumahan melalui bank bank pemerintah salah satunya PT Bank Tabungan Negara (Persero) Tbk.

PT Bank Tabungan Negara (Persero) Tbk sebagai salah satu perusahaan yang turut berperan dalam pemberian kredit perumahan bagi masyarakat Prabumulih terutama masyarakat menengah ke bawah dengan menyalurkan Kredit Pemilikan Rumah (KPR) melalui PT Bank Tabungan Negara (Persero) Tbk Cabang Prabumulih. KPR sendiri dibagi menjadi dua bagian yaitu KPR bersubsidi dan KPR nonsubsidi, KPR subsidi yang diperuntukan untuk masyarakat yang kemampuan ekonominya lemah, sedangkan KPR nonsubsidi diperuntukkan bagi masyarakat yang berpenghasilan tinggi.

Banyak faktor yang mempengaruhi daya beli masyarakat untuk memiliki rumah melalui pembelian tunai ataupun kredit diantaranya pendapatan masyarakat dan suku bunga kredit. Jika pendapatan bertambah maka secara otomatis bagian dari pendapatan yang akan dibelanjakan juga akan bertambah, sehingga daya beli masyarakat atau jumlah barang yang bisa dibeli juga meningkat (Iskandar, 2012).

Berdasarkan Konsep Engel, bahwa semakin tinggi tingkat pendapatan maka semakin rendah porsi pendapatan yang dibelanjakan untuk makanan, dan semakin tinggi pula porsi pendapatan masyarakat yang dibelanjakan untuk kebutuhan non-makanan. Maka dapat dikatakan bahwa apabila pendapatan masyarakat meningkat, maka porsi pendapatan yang dibelanjakan untuk kebutuhan non-makanan khususnya yang digunakan untuk membeli rumah atau membayar cicilan KPR menjadi lebih besar (Soeharjoto, 2012).

Suku bunga kredit merupakan salah satu hal penting yang menjadi pertimbangan masyarakat sebelum mereka memutuskan untuk mengajukan kredit pada bank maupun lembaga keuangan non bank. Menurut Darmawi (2011:181) bahwa tingkat suku bunga merupakan harga yang harus dibayar oleh peminjam untuk memperoleh dana dari pemberi pinjaman untuk jangka waktu yang disepakati. 


\section{Tinjauan Pustaka}

\section{Pendapatan}

Menurut Kieso, Warfield dan Weygantd (2011;955) Pendapatan adalah arus masuk bruto dari manfaat ekonomi yang timbul dari aktivitas normal entitas selama suatu periode, jika arus masuk tersebut mengakibatkan kenaikan ekuitas yang tidak berasal dari kontribusi penanaman modal. Menurut Skousen, Stice dan Stice $(2010 ; 161)$ Pendapatan adalah arus masuk atau penyelesaian (atau kombinasi keduanya) dari pengiriman atau produksi barang, memberikan jasa atau melakukan aktivitas lain yang merupakan aktivitas utama atau aktivitas centra yang sedang berlangsung.

a) Perhitungan pendapatan

Menurut Sadono Sukirno (2010), pendapatan dapat dihitung melalui tiga cara yaitu:

1) Cara Pengeluaran, cara ini pendapatan dihitung dengan menjumlahkan nilai pengeluaran/perbelanjaan ke atas barang-barang dan jasa.

2) Cara Produksi, cara ini pendapatan dihitung dengan menjumlahkan nilai barang dan jasa yang dihasilkan.

3) Cara Pendapatan, dalam penghitungan ini pendapatan diperoleh dengan menjumlahkan seluruh pendapatan yang diterima.

Pendapatan adalah penerimaan bersih seseorang, baik berupa uang kontan maupun natura. Pendapatan atau juga disebut juga income dari seorang warga masyarakat adalah hasil penjualannya dari faktor-faktor produksi yang dimilikinya pada sektor produksi. Dan sektor produksi ini membeli faktor-faktor produksi tersebut untuk digunakan sebagai input proses produksi dengan harga yang berlaku di pasar faktor produksi. Harga faktor produksi di pasar (seperti halnya juga untuk barang-barang di pasar barang) ditentukan oleh tarik menarik, antara penawaran dan permintaan (Poniwati Asmie, 2008).

b) Penggolongan Pendapatan.

Secara garis besar pendapatan digolongkan menjadi tiga golongan (Suparmoko, 2010 dalam Ita Yelli Prihandini, 2013), yaitu : 


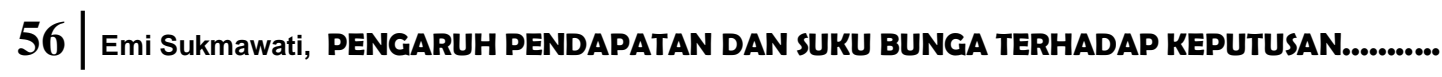

1) Gaji dan Upah. Imbalan yang diperoleh setelah orang tersebut melakukan pekerjaan untuk orang lain yang diberikan dalam waktu satu hari, satu minggu maupun satu bulan.

2) Pendapatan dari Usaha Sendiri. Merupakan nilai total dari hasil produksi yang dikurangi dengan biaya-biaya yang dibayar danusaha ini merupakan usaha milik sendiri atau keluarga dan tenaga kerja berasal dari anggota keluarga sendiri, nilai sewa kapital milik sendiri dan semua biaya ini biasanya tidak diperhitungkan.

3) Pendapatan dari Usaha Lain. Pendapatan yang diperoleh tanpa mencurahkan tenaga kerja, dan ini biasanya merupakan pendapatan sampingan antara lain, pendapatan dari hasil menyewakan asset yang dimiliki seperti rumah, ternak dan barang lain, bunga dari uang, sumbangan dari pihak lain, pendapatan dari pensiun, dan lain-lain.

\section{Suku Bunga}

Menurut Darmawi (2011:181), bahwa tingkat suku bunga merupakan harga yang harus dibayar oleh peminjam untuk memperoleh dana dari pemberi pinjaman untuk jangka waktu yang disepakati. Menurut Boediono (2014:76), Suku Bunga adalah harga yang harus di bayar apabila terjadi pertukaran antara satu Rupiah sekarang dan satu Rupiah nanti. Adanya kenaikan suku bunga yang tidak wajar akan menyulitkan dunia usaha untuk membayar beban bunga dan kewajiban, karena suku bunga yang tinggi akan menambah beban bagi perusahaan sehingga secara langsung akan mengurangi profit perusahaan. Menurut Kasmir (2010:131), bunga bank adalah sebagai balas jasa yang diberikan oleh bank yang berdasarkan prinsip konvensional kepada nasabah yang membeli atau menjual produkanya. Bunga juga dapat diartikan harga yang harus dibayar kepada nasabah (yang memiliki simpanan) dengan yang harus dibayar oleh nasabah kepada bank (nasabah yang memperoleh pinjaman).

a. Macam-macam Suku Bunga.

Berdasarkan pengertian tersebut suku bunga terbagi dalam dua macam yaitu sebagai berikut: 
1) Bunga simpanan yaitu bunga yang diberikan sebagai rangsangan atau balas jasa bagi nasabah yang menyimpan uangnya di bank. Sebagai contoh jasa giro, bunga tabungan, dan bunga deposito.

2) Bunga pinjaman yaitu bunga yang diberikan kepada para peminjam atau harga. Sebagai contoh bunga kredit.

b. Hubungan suku bunga dengan inflasi.

Adapun cara perhitungan Suku Bunga yang menjelaskan ada hubungannya dengan Inflasi dalam formulanya menurut Irving Fisher (1896) yang digunakan sampai sekarang, antara lain :

$$
(1+i)=(1+r)(1+P E) \text { atau } i=r+P E+r . P E
$$

Keterangan :

$\mathrm{i}=$ Suku Bunga nominal (Nominal Interest Rate)

$\mathrm{r}=$ Suku Bunga riil (Real Interest Rate)

$\mathrm{PE}=$ Inflasi yang diharapkan atau diperkirakan (Expected Inflation)

Banyak faktor yang mempengaruhi tingkat bunga, misalnya penentuan tingkat bunga sangat tergantung kepada berapa besar pasar uang domestik mengalami keterbukaan system dana suatu negara, dalam artian penentuan besar penentuan finansial suatu negara yang cenderung berbeda.

c. Unsur-unsur suku bunga

Unsur-unsur di dalam tingkat suku bunga meliputi:

1) Syarat jatuh tempo

Berbagai pinjaman mempunyai syarat jatuh tempo. Surat-surat berharga jangka pendek biasanya mempunyai periode sampai dengan satu tahun. Surat-surat berharga jangka panjang umumnya memberikan suku bunga yang lebih tinggi dibandingkan dengan jangka pendek.

2) Risiko

Ada pinjaman yang pada hakikatnya tidak memiliki risiko, sementara lainnya sangat bersifat spekulatif. Obligasi-obligasi dan tagihan-tagihan pemerintah didukung dengan penuh kepercayaan oleh kredit dan kekuatan pajak dari pemerintah. Unsur-unsur 


\section{8}

Emi Sukmawati, PeNGARUH PENDAPATAN DAN SUKU BUNGA TERHADAP KEPUTUSAN.

ini dapat dipercaya karena bunga pinjaman pemerintah akan benar-benar dibayar. Risiko menengah terdapat pada pinjaman kredit-kredit perusahaan yang kondisinya baik. Investasi yang berisiko mempunyai peluang gagal atau tidak dibayar yang sangat tinggi termasuk investasi pada perusahaan yang hamper bangkrut.

3) Likuiditas

Aktiva akan disebut "likuid" apabila dapat ditukarkan dengan kas secara cepat dan hanya menimbulkan kerugian nilai yang sedikit. Sebagian besar surat berharga termasuk saham, obligasi perusahaan dan pemerintah dapat diukur dengan kas secara cepat mendekati nilai sekarang.

4) Biaya-biaya administrasi

Waktu dan ketelitian yang diperlukan untuk administrasi berbagai jenis pinjaman sangatlah berbeda. Pinjaman dengan biaya administrasi yang tinggi mempunyai bunga 5 sampai 10 persen per tahun lebih besar dari tingkat bunga lainnya.

Tinggi atau rendahnya suku bunga sangat menentukan sekali dalam pertumbuhan ekonomi dalam bidang sektor riil yang banyak menyerap tenaga kerja, begitu juga dengan pertumbuhan investasi yang dapat mendongkrak pertumbuhan ekonomi secara proporsional.

\section{Pengambilan Keputusan.}

Menurut Semuel Schiffman dan Kanuk (2004) keputusan pembelian adalah pemilihan dari dua atau lebih alternatif pilihan yang ada, artinya bahwa syarat seseorang dapat membuat keputusan haruslah tersedia beberapa alternatif pilihan. Keputusan untuk membeli dapat mengarah kepada bagaimana proses dalam pengambilan keputusan tersebut itu dilakukan.

Persepektif pengambilan keputusan menekankan pendekatan pemrosesan informasi yang rasional terhadap perilaku pembelian konsumen (Mowen dan Minor 2002).

Pengambilan keputusan oleh konsumen untuk melakukan pembelian suatu produk diawali oleh adanya kesadaran atas pemenuhan kebutuhan-kebutuhan dan keinginan disebut need arousal (Sutisna 2003). 
Jika sudah disadari adanya kebutuhan dan keinginan, maka konsumen akan mencari informasi mengenai keberadaan produk yang diinginkannya. Dalam mengenal konsumen perlu mempelajari perilaku konsumen sebagai perwujudan dari seluruh aktivitas jiwa manusia dalam kehidupan sehari-hari. Persepsi-persepsi pengaruh orang lain dan motif-motif internal akan berinteraksi untuk menentukan keputusan terakhir yang dianggap paling sesuai.

Perilaku konsumen adalah tindakan-tindakan yang dilakukan individu, kelompok atau organisasi yang berhubungan dengan proses pengambilan keputusan dalam mendapatkan, menggunakan barang-barang atau jasa ekonomis yang dapat dipengaruhi oleh lingkungan (Swastha 2003).

\section{Kerangka Pemikiran}

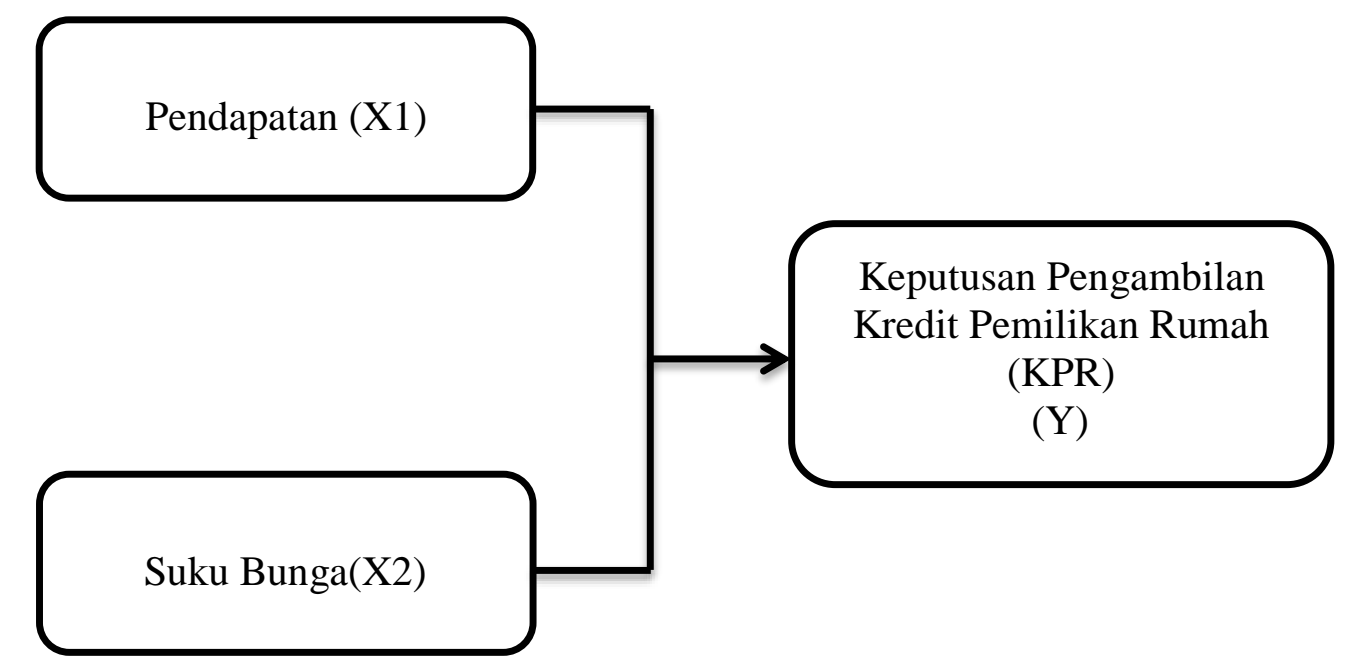

Sumber: Penulis berdasarkan teori

Gambar 2.1

Kerangka Pemikiran

\section{Metode Penelitian}

\section{Tempat Penelitian}

Penelitian ini dilakukan di Kota Prabumulih yang meliputi beberapa wilayah kecamatan diantaranya Kecamatan Prabumulih Utara, Prabumulih Selatan, Prabumulih 


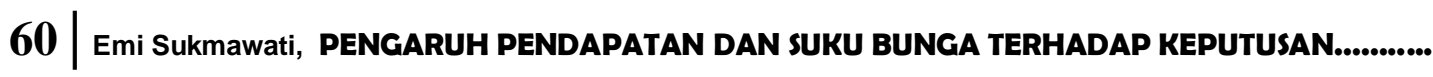

Timur, Prabumulih Barat, Cambai dan Rambang Kapak Tengah. Juga dilakukan pada PT Bank Tabungan Negara (Persero) Tbk Cabang Prabumulih.

\section{Populasi dan Sampel}

Populasi adalah wilayah generalisasi yang terdiri dari obyek/subyek yang menjadi kuantitas dan karakteristik tertentu yang ditetapkan oleh peneliti untuk dipelajari dan kemudian ditarik kesimpulannya (Sugiyono, 20010:90). Populasi dalam penelitian ini adalah masyarakat di Kota Prabumulih.

Sampel adalah bagian dari populasi yang digunakan untuk memperkirakan karakteristik populasi (Sugiyono, 2010:91). Penentuan sampel pada penelitian ini adalah dengan menggunakan metode accidental sampling yaitu pengambilan sampel secara acak. Adapun jumlah sampel yang diteliti sebanyak 100 responden yang bekerja, baik sebagai karyawan swasta, pegawai BUMN, maupun Pegawai Negeri Sipil (PNS) yang diklasifikasikan berdasarkan pendapatan yang diterimanya perbulan.

\section{Jenis dan Sumber Data}

Data yang digunakan dalam penelitian ini terbagi atas:

a. Data Primer

Data primer merupakan sumber data penelitian yang diperoleh secara langsung dari sumber asli (tidak melalui perantara). Data primer secara khusus dikumpulkan untuk menjawab pertanyaan penelitian (Indiriantoro, 2009). Dalam penelitian ini data diambil berdasarkan kuesioner yang diwawancarakan kepada responden. Data primer tersebut meliputi identitas responden secara umum, dan hal yang berkaitan dengan pendapatan dan suku bunga KPRyang dibagikan kepada responden atau nasabah yang mengambil KPR pada PT Bank Tabungan Negara (Persero) Tbk Cabang Prabumulih.

b. Data Sekunder

Data sekunder merupakan sumber data penelitian yang diperoleh peneliti secara tidak langsung melalui media perantara atau diperoleh dan dicatat oleh pihak lain (Indriantoro, 2009). Dalam penelitian ini data diperoleh dari PT Bank Tabungan Negara (Persero) Tbk Cabang Prabumulih, Bank Indonesia dan Kantor Badan Pusat Statistik di Kota Prabumulih serta literatur-literatur lain yang membahas mengenai materi penelitian tersebut. 


\section{Metode Pengumpulan Data}

a. Penelitian lapangan yaitu pengambilan data di daerah/ lokasi penelitian dengan teknik pengumpulan data sebagai berikut:

1). Observasi

Teknik ini digunakan untuk mendeskripsikan tentang keadaan lapangan dengan pengamatan yang dilakukan terhadap pemegang polis yang senantiasa bersifat obyektif faktual. Tujuannya untuk memperoleh gambaran yang lengkap mengenai keadaan lokasi penelitian.

2). Interview

Untuk mendapatkan informasi yang akurat dan lengkap mengenai nasabah, maka dilakukan wawancara terhadap narasumber dan responden yaitu nasabah.

3) Kuisioner

Digunakan untuk merekam data tentang kegiatan nasabah. Pengisian kuisioner dilakukan secara terstruktur dengan mempergunakan daftar pertanyaan yang telah disiapkan.

b. Penelitian kepustakaan (library research)

Penelitian kepustakaan yaitu melalui beberapa buku bacaan, literatur atau keterangan-keterangan ilmiah untuk memperoleh teori yang melandasi dalam menganalisa data yang diperoleh dari lokasi penelitian.

\section{Metode Analisis}

Dalam analisis dan pengolahan data, dilakukan beberapa pengujian yang meliputi uji asumsi klasik, regresi linier berganda dan pengujian hipotesis dengan menggunakan program bantuan komputer yaitu SPSS 16.0 for Windows.

a. Uji Asumsi Klasik

1). Uji Normalitas

Bertujuan untuk menguji apakah dalam model regresi variabel dependen dan independen keduanya mempunyai distribusi normal atau tidak.Model regresi yang baik adalah memiliki distribusi data normal atau mendekati normal. Uji normalitas pada penelitian ini menggunakan Normal P-Plot of regressionstandardized residual terhadap pengujian pada keseluruhan variabel dalam penelitian ini. Uji normalitas data dilihat P-ISSN : 2460-9595 


\section{2}

Emi Sukmawati, PENGARUH PENDAPATAN DAN SUKU BUNGA TERHADAP KePUTUSAN.

dengan melihat pola pada kurva penyebaran pada Grafik P-Plot.Jika pola penyebaran memiliki garis normal kurva maka dapat dikatakan data berdistribusi normal.

2). Uji Multikolinearitas

Uji ini digunakan untuk menguji apakah dalam sebuah model regresi ditemukan adanya korelasi antar variabel independen. Jika terjadi korelasi, maka dikatakan terdapat masalah multikolinearitas. Model regresi yang baik seharusnya tidak terjadi korelasi antar variabel independen. Pengujian terhadap ada tidaknya multikolinearitas dilakukan dengan metode VIF (Variance Inflation Factor) dengan ketentuan :

Bila VIF > 10 terdapat masalah multikolinearitas

Bila VIF $<10$ tidak terdapat masalah multikolinearitas

3). Uji Autokorelasi

Uji asumsi autukorelasi bertujuan untuk menguji apakah dalam suatu model regresi linier ada korelasi antara kesalahan pengganggu pada periode $\mathrm{t}$ dengan kesalahan pengganggu pada periode t-1 (Singgih Santoso, 2010: 213). Model regresi yang baik, tidak terjadi autokorelasi. Untuk mendiagnosis adanya autokorelasi dalam suatu model regresi, maka dilakukan pengujian terhadap nilai uji Durbin Watson. Menurut Singgih Santoso (2010: 215), pengambilan keputusan ada tidaknya autokorelasi, sebagai berikut;

a) Angka D-W dibawah -2, berarti ada autokorelasi positif

b) Angka D-W diantara -2 sampai +2 , berarti tidak ada autokorelasi,

c) Angka D-W di atas +2 , berarti ada autokorelasi negatif

4). Uji Heterokedastisitas

Heteroskedastisitas adalah variabel pengganggu dimana memiliki varian yang berbeda dari satu observasi ke observasi lainnya atau varian antar variabel independen tidak sama, hal ini melanggar asumsi homokedastisitas yaitu setiap variabel penjelas memiliki varian yang sama (konstan). Untuk menentukan heterokedastisitas dapat menggunkan metode grafik yaitu scatterplot, titik-titik harus menyebar secara acak, tersebar baik di atas maupun di bawah angka 0 pada sumbu $\mathrm{Y}$, bila kondisi ini terpenuhi maka tidak terjadi heterokedastisitas dan model regresi layak digunakan. 
b. Regresi Linier Berganda

Regresi linear berganda digunakan untuk mengetahui pengaruh antara variabel bebas dengan variabel terikat, yaitu pendapatan dan suku bunga terhadapkeputusan pengambilan KPR pada PT Bank Tabungan Negara (Persero) Tbk Cabang Prabumulih.

Model regresi yang digunakan adalah :

$$
\mathrm{Y}=\mathrm{a}+\mathrm{b}_{1} \mathrm{X}_{1}+\mathrm{b}_{2} \mathrm{X}_{2}+\varepsilon
$$

Keterangan :

$\mathrm{Y}=$ Keputusan Pengambilan KPR

$\mathrm{a}=$ Harga konstanta (harga $\mathrm{Y}$ bila $\mathrm{X}=0$ )

$\mathrm{b}_{1,2}=$ Harga koefisien regresi

$\mathrm{X}_{1}=$ Variabel independen pertama (Pendapatan)

$\mathrm{X}_{2}=$ Variabel independen kedua (Suku Bunga)

$\varepsilon=$ Error term

c. Pengujian Hipotesis

Adapun pengujian hipotesis dilakukan dengan langkah-langkah sebagai berikut:

1) Uji Simultan (Uji F)

Pengujian ini bertujuan untuk mengetahui pengaruh semua variabel independen secara simultan terhadap variabel dependen (Priyatno, 2013:122). Pembuktian dilakukan dengan cara membandingkan nilai $\mathrm{F}$ hitung dengan $\mathrm{F}$ tabel. Untuk menentukan nilai $\mathrm{F}$ tabel, tingkat signifikansi yang digunakan sebesar 5\% dengan derajat kebebasan (degrees of freedom) df1 = (jumlah total variabel-1) dan df $2=$ (n-k-1) di mana $\mathrm{n}$ adalah jumlah sampel (data) dan $\mathrm{k}$ adalah jumlah variable independen. Kriteria pengujian yang digunakan adalah:

a) Jika $\mathrm{F}$ hitung $\leq \mathrm{F}$ tabel, maka Ho diterima berarti variabel independen secara bersama-sama tidak berpengaruh secara signifikan terhadap variabel dependen.

b) Jika $\mathrm{F}$ hitung $>\mathrm{F}$ tabel, maka Ho ditolak berarti variabel independen secara bersama-sama berpengaruh secara signifikan terhadap variabel dependen.

2) Uji Parsial (Uji t)

Pengujian ini bertujuan untuk memastikan apakah variabel independen secara parsial yang berpengaruh terhadap nilai variabel dependen (Priyatno, 2013:120). Uji t P-ISSN : 2460-9595 
dilakukan dengan membandingkan antara t-hitung dengan t-tabel. Untuk menentukan nilai t-tabel ditentukan dengan tingkat signifikansi 5\% dan 2 sisi dengan derajat kebebasan df $=(\mathrm{n}-\mathrm{k}-1)$ di mana $\mathrm{n}$ adalah jumlah sampel (data) dan $\mathrm{k}$ adalah jumlah variabel independen. Adapun kriteria pengujian yang digunakan adalah :

a) Jika t-hitung $\leq \mathrm{t}$-tabel, maka Ho diterima, berarti variabel independen secara parsial tidak berpengaruh signifikan terhadap variabel dependen.

a) Jika t-hitung > t-tabel, maka Ho ditolak, berarti variabel independen secara parsial berpengaruh signifikan terhadap variabel dependen.

3) Koefisien Determinasi (R2)

Untuk melihat seberapa besar pengaruh variabel independent atau bebas dalam menerangkan secara keseluruhan terhadap variabel dependen atau terikat serta pengaruhnya secara potensial dapat diketahui dari besarnya nilai koefisien determinasi $\left(\mathrm{R}^{2}\right)$ yang dirumuskan sebagai berikut:

Jonathan Sarwono (2012:50) mengemukakan rumus koefisien determinasi sebagai berikut:

$$
\mathrm{KD}=\mathrm{r}^{2} \times 100 \%
$$

Dimana :

$\mathrm{KD}=$ Koefisien Determinasi

$\mathrm{r}=$ Koefisien Korelasi

Dalam melakukan analisis kuantitatif, peneliti menggunakan bantuan program SPSS 16For Windows dan Ms. Office Exell 2010.

\section{Hasil Dan Pembahasan}

\section{Sejarah Singkat PT. Bank Tabungan Negara (Persero) Tbk}

PT. Bank Tabungan Negara (Persero) Tbk dimulai dengan didirikannya Postpaarbank tahun 1897. Pada tahun 1942, sejak masa pendudukan Jepang di Indonesia, bank ini dibekukan dan digantikan dengan Tyokin Kyoku atau Chokinkyoku. Setelah proklamasi kemerdekaan Indonesia bank ini diambil alih oleh pemerintah 
Indonesia dan diubah menjadi Kantor Tabungan Pos. Nama dan bentuk perusahaan selanjutnya berubah beberapa kali hingga akhirnya pada tahun 1963 diubah menjadi nama dan bentuk resmi yang berlaku saat ini yaitu menjadi Bank Tabungan Negara. Pada tahun 1968 Bank Tabungan Negara resmi dimiliki pemerintah dan menjadi salah satu Badan Usaha Milik Negara (BUMN).

PT. Bank Tabungan Negara (Persero) Tbk mulai terus mengembangkan usahanya dengan membuka beberapa cabang di setiap provinsi dan kota besar di Indonesia, salah satunya mebuka cabang dikota Prabumulih. Dan resi pada bulan Oktober 2016 PT. Bank Tabungan Negara (Persero) Tbk membuka cabang di Kota Prabumulih. PT. Bank tabungan Negara (Persero) Tbk didirikan sebagai institusi yang menyalurkan Kredit Perumahan Rakyat (KPR) bagi golongan masyarakat menengah ke bawah dan juga ditumjuk pemerintah sebagai pembayaran rumah komersial.

\section{Sampel Penelitian.}

Jumlah sampel sebanyak 100 responden yang bekerja, baik sebagai karyawan swasta, pegawai BUMN, maupun Pegawai Negeri Sipil (PNS) yang diklasifikasikan berdasarkan pendapatan yang diterimanya perbulan dan semuanya diberikan kuesioner.

\section{Hasil Peneltian.}

\section{a. Hasil Uji Penelitian}

\section{1). Regresi Linier Berganda}

Regresi linear berganda digunakan untuk mengetahui pengaruh antara variabel bebas dengan variabel terikat, yaitu pendapatan dan suku bunga terhadapkeputusan pengambilan KPR pada PT Bank Tabungan Negara (Persero) Tbk Cabang Prabumulih. Model regresi yang digunakan adalah :

$$
Y=a+b_{1} X_{1}+b_{2} X_{2}+\varepsilon
$$

Keterangan :

$\mathrm{Y}=$ Keputusan Pengambilan KPR

$\mathrm{a}=\operatorname{konstanta}(\mathrm{Y}$ bila $\mathrm{X}=0$ )

$\mathrm{b}_{1,2}=$ koefisien regresi 


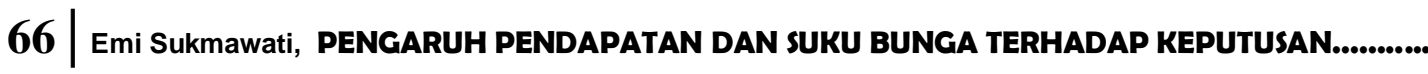

$\mathrm{X}_{1}=$ Variabel independen pertama (Pendapatan)

$\mathrm{X}_{2}=$ Variabel independen kedua (Suku Bunga)

$\varepsilon=$ Error term

Tabel 1.

Hasil Regresi Linier Berganda

Coefficients $^{\text {a }}$

\begin{tabular}{|c|c|c|c|c|c|c|}
\hline \multirow{2}{*}{\multicolumn{2}{|c|}{ Model }} & \multicolumn{2}{|c|}{$\begin{array}{c}\text { Unstandardized } \\
\text { Coefficients }\end{array}$} & \multirow{2}{*}{$\begin{array}{c}\text { Standardized } \\
\text { Coefficients } \\
\text { Beta }\end{array}$} & \multirow[b]{2}{*}{$\mathrm{t}$} & \multirow[b]{2}{*}{ Sig. } \\
\hline & & B & Std. Error & & & \\
\hline 1 & (Constant) & 6.579 & 1.754 & & 3.751 & .000 \\
\hline & Pendapatan & .315 & .079 & .334 & 4.007 & .000 \\
\hline & Suku Bunga & .419 & .075 & .464 & 5.574 & .000 \\
\hline
\end{tabular}

a. Dependent Variable: Keputusan Pengambilan KPR

Berdasarkan tabel di atas, dapat disusun persamaan regresi linier berganda sebagai berikut :

$$
\begin{aligned}
& Y=a+b 1 X 1+b 2 X 2+\varepsilon \\
& Y=6,579+0,315 X 1+0,419 X 2+\varepsilon
\end{aligned}
$$

Dimana:

$\mathrm{Y}=$ Keputusan Pengambilan KPR $\quad \mathrm{X} 1=$ Pendapatan $\quad \mathrm{X} 2=$ Suku Bunga

Dari tabel dan persamaan regresi linier berganda di atas dapat diinterpretasikan sebagai berikut:

1). Nilai konstanta ( $\boldsymbol{\alpha})$ sebesar 6,579 artinya jika variabel pendapatan dan suku bunga diasumsikan bernilai nol, maka variabel return saham akan bernilai positif sebesar 6,579 .

2). Nilai koefisien regresi variabel pendapatan bernilai positif sebesar 0,315 artinya jika pendapatan mengalami kenaikan satu satuan, maka keputusan pengambilan KPR akan mengalami peningkatan sebesar 0,315 satuan dengan asumsi variabel independen lainnya bernilai tetap.

3). Nilai koefisien regresi variabel suku bunga bernilai positif sebesar 0,419 artinya bahwa suku bunga berpengaruh positif terhadap keputusan pengambilan KPR.

\section{2). Pengujian Hipotesis}


Adapun pengujian hipotesis dilakukan dengan langkah-langkah sebagai berikut:

\section{a). Uji Simultan (Uji F)}

Tabel 2. Hasil Uji F

ANOVA $^{b}$

\begin{tabular}{|l|r|r|r|r|r|}
\hline Model & Sum of Squares & Df & Mean Square & F & \multicolumn{1}{c|}{ Sig. } \\
\hline $1 \quad$ Regression & 363.325 & 2 & 181.662 & 42.601 & .000 \\
Residual & 413.635 & 97 & 4.264 & & \\
Total & 776.960 & 99 & & & \\
\hline
\end{tabular}

a. Predictors: (Constant), Suku Bunga, Pendapatan

b. Dependent Variable: Keputusan Pengambilan KPR

Dari hasil output di atas diperoleh nilai F hitung sebesar 42,601. Adapun nilai F tabel diperoleh dengan cara $\mathrm{F}$ tabel dengan df1 = 2 dan df $2=100-2-1=97$.

Maka nilai F tabel yaitu: 3,090. Jadi nilai F hitung $(42,601)>F$ tabel $(3,090)$ maka Ho ditolak artinya ada pengaruh secara signifikan variabel independen (pendapatan dan suku bunga) terhadap variabel dependen (keputusan pengambilan KPR).

b). Uji Parsial (Uji t)

\section{Tabel 3. Hasil Uji t}

Coefficients $^{\mathbf{a}}$

\begin{tabular}{|c|c|c|c|c|c|c|}
\hline \multirow{2}{*}{\multicolumn{2}{|c|}{ Model }} & \multicolumn{2}{|c|}{$\begin{array}{c}\text { Unstandardized } \\
\text { Coefficients }\end{array}$} & \multirow{2}{*}{$\begin{array}{l}\begin{array}{c}\text { Standardized } \\
\text { Coefficients }\end{array} \\
\text { Beta }\end{array}$} & \multirow[b]{2}{*}{$\mathrm{t}$} & \multirow[b]{2}{*}{ Sig. } \\
\hline & & B & Std. Error & & & \\
\hline \multirow[t]{3}{*}{1} & (Constant) & 6.579 & 1.754 & & 3.751 & .000 \\
\hline & Pendapatan & .315 & .079 & .334 & 4.007 & .000 \\
\hline & Suku Bunga & .419 & .075 & .464 & 5.574 & .000 \\
\hline
\end{tabular}

a. Dependent Variable: Keputusan Pengambilan KPR

Berdasarkan Output di atas disimpulkan bahwa variabel pendapatan (X1) lebih besar daripada nilai t tabel $(4,007>1,660)$ dengan tingkat signifikan di bawah 0,05 
68 Emi Sukmawati, PENGARUH PENDAPATAN DAN SUKU BUNGA TERHADAP KEPUTUSAN...........

yaitu 0.000 dan t hitung variabel suku bunga (X2) lebih besar daripada nilai t tabel $(5,574>1,660)$ dengan tingkat signifikan di bawah 0,05 yaitu 0.000. Maka dapat disimpulkan bahwa:

a. Variabel pendapatan secara parsial berpengaruh signifikan terhadap keputusan pengambilan KPR.

b. Variabel suku bunga secara parsial berpengaruh signifikan terhadap keputusan pengambilan KPR.

c). Koefisien Determinasi $\left(\mathbf{R}^{2}\right)$

Tabel 4.

Koefisien Determinasi

Model Summary ${ }^{\text {b }}$

\begin{tabular}{|l|r|r|r|r|}
\hline Model & $\mathrm{R}$ & \multicolumn{1}{|c|}{ R Square } & Adjusted R Square & \multicolumn{2}{c|}{$\begin{array}{c}\text { Std. Error of the } \\
\text { Estimate }\end{array}$} \\
\hline 1 & $.684^{\mathrm{a}}$ & .468 & .457 & 2.065 \\
\hline
\end{tabular}

a. Predictors: (Constant), Suku Bunga, Pendapatan

b. Dependent Variable: Keputusan Pengambilan KPR

Berdasarkan hasil penghitungan SPSS seperti pada tabel di atas dapat diketahui bahwa pengaruh kedua variabel bebas (independen) terhadap variabel dependen dinyatakan dengan nilai koefisien determinasi $\left(\mathrm{R}^{2}\right)$ yaitu sebesar 0.468 atau $46,8 \%$. Hal ini menunjukkan bahwa persentase sumbangan pengaruh variabel independen terhadap variabel dependen sebesar 46,8\%. Sedangkan sisanya sebesar $100 \%-46,8 \%=53,2 \%$ dipengaruhi oleh variabel lain yang tidak dimasukkan dalam model penelitian ini.

\section{Simpulan}

Dari penelitian yang dilakukan maka dapat disimpulkan bahwa pendapatan dan suku bunga berpengaruh terhadap keputusan pengambilan KPR pada PT. Bank Tabungan Negara (Persero) Tbk Cabang Prabumulih adalah sebesar 46,8\%. Sedangkan saran yang dapat peneliti berikan adalah sebagai berikut: 
1. Bagi Perusahaan yang bergerak dibidang perumahan hendaknya benar-benar memperhatikan faktor-faktor apa saja yang sangat berpengaruh dalam menentukan keputusan pembeli untuk pengambilan KPR agar perusahaan terhindar dari masalah yang tidak diinginkan.

2. Bagi peneliti selanjutnya, diharapkan tidak hanya menggunakan variabel penelitian ini saja, tetapi menambahkan variabel independen penelitian selain pendapatan dan suku bunga agar hasil yang didapat lebih akurat.

\section{DAFTAR PUSTAKA}

Alfansi, Lizar. 2012. Pemasaran Jasa Finansial. Jakarta: Salemba Empat ,2016.

Alma, Buchari 2016. Manajemen Pemasaran dan Pemasaran Jasa. Penerbit Alfabeta, Bandung

Alma Buchari, 2010. Manajemen Pemasaran dan Pemasaran Jasa. Penerbit Alfabeta,Bandung.

Aravik, Havis, Hamzani, Achmad Irwan. 2019. Homo Islamicus dan Imperfect State : Konsep Manusia dan Al-Madinah Al-Fadilah menurut Al-Farabi, Al-Falah: Journal of Islamic Economics, Vol. 4, No. 1.

Boediono. 2014. Ekonomi Moneter.Edisi ketiga, BPFE Universitas Gajah Mada, Yogyakarta. Teori Moneter. Yogyakarta: BPFE UGM.

Bank Indonesia (BI), http://www.bi.go.id

Biro Pusat Statistik (BPS), http://www.bps.go.id

Dharmmesta, Basu Swastha dan Handoko, T.Hani 2016. Manajemen Pemasaran Analisis Perilaku Konsumen. Penerbit BPFE-Yogyakarta.

Ghozali, I. 2005. Aplikasi Analisis Multivariate Dengan Program SPSS. Badan Penerbit Universitas Diponegoro. Semarang.

Griffin, 2005. Manajemen edisi 7 jilid 1.Penerbit Erlangga Ciracas,Jakarta

Ginting, Paham dan Sembiring, Beby KF. 2010. Dosen Magister IlmuManajemen SPs USU

Jasfar,F.2009. Manajemen Jasa Pendekatan Terpadu. Ghalia Indonesia Jakarta

Kasmir. 2010. Bank Dan Lembaga Keuangan Lainnya. Edisi Revisi 8. Jakarta: PT Raja Grafindo Persada. 
70 | Emi Sukmawati, PENGARUH PENDAPATAN DAN SUKU BUNGA TERHADAP KEPUTUSAN.............

Kieso D E J J Weygandt and T D Warfield 2011. Intermadiate Accounting. Ahli Bahasa Emil Salim. Jakarta: Erlangga

Kotler dan Amstrong. 2012. Prisnsip-prinsip Pemasaran. Edisi 13.Jilid 1.Jakarta:Erlangga

Kotler, P. \& Keller, K. L. 2012. Marketing Management (14th ed.). United States of America : Pearson

Lupiyoadi, R. 2013. Manajemen Pemasaran Jasa Berbasis Kompetensi. (Edisi Ketiga.).Jakarta: Salemba Empat.

Madura,Jeff. (2011: p.449). Pengantar Bisnis .Penerbit Salemba Empat edisi 4 buku 1 dan 2 .Jakarta.

Morissan, 2010. Periklanan: KomunikasiPemasaran Terpadu. Bogor: Prenada

Nafarin. 2010. Penganggaran Perekonomian. Jakarta: Salemba Empat

Nazir ,Moh. 2009. Metode Penelitian .Jakarta: Ghalia Indonesia.

Niswonger. 2012. Prinsip-prinsip Akuntansi. Jakarta: Erlangga

Priyatno Duwi. 2013. Mandiri Belajar Analisis Data Dengan SPSS. Yogyakarta: Mediakom.

Rangkuti, F. 2006. Riset Pemasaran. (5th ed.). Jakarta: Gramedia Pustaka Utama.

Sadono Sukirno. 2010. Makro Ekonomi. Jakarta: PT Raja Grafindo Persada

Skousen, Stice. 2010. Akuntansi Keuangan. Jakarta: Salemba Empat.

Saebani,Beni Ahmad. 2015. Perilaku Konsumen Teori dan Praktik. Penerbit: PustakaSetia,Bandung

Siagian,S.P.2007. Manajemen Sumberdaya Manusia. (14th ed.). Jakarta: Penerbit Bumi Aksara.

Sugiyono. 2010. Metode Penelitian Kuantitatif Kualitatif dan R\&D. Bandung: Alfabeta

Sunyoto, Danang. 2014. Praktik Riset Perilaku Konsumen. Penerbit: PT.BUKU SERU, Jakarta

Suyanto, Asep Herman. 2007. Web Design Theory and Practices.Yogyakarta: Andi

Swastha, B. Dharmmesta dan Handoko, T Hani. 2016.Manajemen Pemasaran, Analiiss Konsumen. Edisi Pertama di cetak BPFE-Yogyakarta cetakan ketujuh agustus 2016

Tjiptono, F. 2014. Pemasaran Jasa. Penerbit Andi. Yogyakarta (Wyckof dalam Lovelock yang dikutip oleh Fandy Tjiptono, 2012) Konsep Kualitas Pelayanan Publik

Umar, Husein, 2010, Riset Pemasaran Dan Perilaku Konsumen. Penerbit PT.Gramedia Bulding, Jakarta 
Yazid. 2003. Pemasaran Jasa, Edisi Kedua, Fakultas Ekonomi UII, Yogyakarta.

Zeithaml, V.A., Bitner, M.J. \& Gremler, D.D. 2006. Service marketing. $4^{\text {th }}$ edition. New York: The MC Graw-Hill Companies, Inc.

Zamzam, Fakhry, Aravik Havis. 2016. Manajemen SDM Berbasis Syariah, Bogor: CV. RWTC Success. 
72 | Emi Sukmawati, PENGARUH PENDAPATAN dan SUKU BUNGA TERHADAP KEPUTUSAN............ 